\title{
'Change the Heart, and the Work Will Be Changed': Pius XII's Papal Blueprints for Europe
}

\author{
Dorien Lanting and Trineke Palm (D) \\ History and Art History, Utrecht University, Drift 6, 3512 BS Utrecht, the Netherlands \\ dorienlanting@gmail.com \\ History and Art History, Utrecht University, Drift 6, 3512 BS Utrecht, the Netherlands \\ t.p.palm@uu.nl
}

This article examines the role of emotions in papal discourse about European integration. Expanding on the 'emotional turn' in history, it develops an analytic framework to study emotional valence in constructing the past and future. Analysing Pope Pius XII's three major post-war encyclicals (Communium Interpretes Dolorum, Fulgens Radiatur and Summi Maeroris), this article shows how the emotional vocabulary of Pius XII bridges the gap between theology and politics. In particular, it illuminates how Pope Pius XII integrated emotional and religious vocabulary to (re)construct an image of a European past and future.

The pontificate of Pope Pius XII, from 1939 to 1958, was characterised by international and domestic turbulence. His reign saw both a world war and the beginning of European integration, a metamorphosis on all societal levels. This transformation was not just about the pooling of coal and steel, but rather an intricate process that involved interests, ideas and emotions. Central to this article is the role of Pius XII in nudging a perspective on European unity among his readership, through the use of emotional vocabulary in his encyclicals.

As the first pope to promulgate a distinctive view on European affairs, ${ }^{1}$ the writings of Pope Pius XII are of particular interest in the context of the European project. The experience of the Second World War led Pius XII to advocate for a more peaceful coexistence in Europe, guided by Catholic morals. During his pontificate he welcomed the first European treaties, such as the European Coal and Steel Community and the (efforts for) the European Defence Community. ${ }^{2}$ Beyond such support, he actively promoted a particular conception of a united Europe in some of his encyclicals, by means of emotional vocabulary that connected shared experiences with a positive or negative anticipation of the future. With his religious authority and transnational reach, Pope Pius XII's influence in shaping the emotional climate of European integration cannot be ignored.

The relationship between religion and politics has always been complex. That includes the involvement of the Catholic Church in worldly affairs such as (international) political and economic negotiations. Its involvement in the process of European integration has attracted considerable scholarly attention. Already in the 1950s, Pius XII was criticised for interfering too much with European

1 Blandine Chelini-Pont, 'Papal Thought on Europe and the European Union in the Twentieth Century', Religion, State \& Society, 37, 1-2 (2009), 132.

2 See for example Pius XII, 'Nous sommes très sensible' address on the occasion of the Second International Congress for the foundation of the European Federal Union' (Castelgandolfo, 11 Nov. 1948), at which time Pius expressed his support for the Federalist Movement's actions in support of European unity. Later, in 1957, in an address to participants in a Congress promoted by the European Movement, he reiterated this support, explicitly mentioning the European Coal and Steel Community (ECSC) and the failed European Defence Community (EDC) project: 'Discorso di sua santità Pio PP. XII, ai partecipanti al congresso d'Europa', The Pope Speaks, 4-2, 201-4.

(c) The Author(s), 2021. Published by Cambridge University Press. This is an Open Access article, distributed under the terms of the Creative Commons Attribution licence (https://creativecommons.org/licenses/by/4.0/), which permits unrestricted re-use, distribution, and reproduction in any medium, provided the original work is properly cited. 
affairs. ${ }^{3}$ More recently, sociologist of religion José Casanova claimed that the European Union 'was fundamentally a Christian Democratic project, sanctioned by the Vatican'. ${ }^{4}$ On the other hand, scholars such as the Vatican expert Philippe Chenaux are more critical of this image of the Holy See as patron of the European project. ${ }^{5}$ The historian Wolfram Kaiser stressed that ' $\left.t\right]$ he origins of the Christian democratic policies for core European integration were not in the Vatican'. ${ }^{6}$ Beyond the political dimension, there is another side to the relation of church and politics: theology. Much less concerned with the (limits of) papal political interference, but rather with the development of papal thought on politics, is the work of scholars such as the Christian church expert Anthony O'Mahony. He analysed the political ideology in papal statements and found a more or less continuous 'Idea of Europe' in twentieth-century papal thought. ${ }^{7}$ Blandine Chelini-Pont, on the other hand, highlighted in his Papal Thought on Europe and the European Union in the Twentieth Century, the development and changes of these papal views on European integration. ${ }^{8}$

This article moves beyond the theology or political influence of Pope Pius XII. It aims to connect the religious beliefs of Catholicism with the process of European integration by analysing the relatively underexposed role of emotions in papal discourse about European integration. Existing research on studying the history of emotions has pointed out how our emotional lexicon has changed over time, and how emotions are central to our understanding of both continuity and change. ${ }^{9}$ As Joachim Häberlan and Russell Spinney have shown in their special issue on Emotions in Protest Movements, emotions have been a critical device in the politics of protest movements. ${ }^{10}$ Joining this thriving debate on the role of emotions in history, this article draws attention to the interaction between religious beliefs, emotions and international politics, by examining the question of how emotives substantiated the Catholic blueprint for European unity by Pope Pius XII (1945-50).

This Catholic blueprint emerges from three post-war encyclicals written by Pope Pius XII. Encyclicals, formal papal letters, have been an important way to translate Catholic religious beliefs to contemporary issues in society. They reach a transnational audience, ranging from bishops to clergy, to the Catholic family home. Their relevance for the current research lies in their function: encyclicals are specifically intended to give moral guidance to the readership, often on a particular subject or theme. They connect Catholic social doctrine and the European project. Therefore, studying emotives in encyclicals on European integration sheds new light on the institutional set-up of post-war European integration. The focus on the role of emotions and personal experience allows us to see the functionality of the text in a broader context than strictly theological or political motives. Central to our analytic framework is the distinction between positive valence (amity) and negative valence (enmity) in its relation to the interpretation of the past (i.e. 'space of experience') and

\footnotetext{
3 The idea that the Vatican was (too) (heavily) involved in the post-war European project is oft repeated. For example, the socialist Guy Mollet expressed his annoyance during a heated debate on the European Defence Community: 'The failed ratification of the EDC at the French National Assembly (30 Aug. 1954) will be very painfully felt in the Vatican'. Quote derived from Philippe Chenaux, collected by Jean-Dominique Durand, Une crise chrétienne de l'Europe? L'urgence européenne (Sion, Parole et Silence, 2013), 103-112.

4 José Casanova, 'Religion, European Secular Identities and European Integration', in Timothy A. Byrnes and Peter J. Katzenstein, eds., Religion in an Expanding Europe (Cambridge: Cambridge University Press, 2006), 66.

5 Philippe Chenaux, Une Europe vaticane? Entre le Plan Marshall et les traits de Rome (Brussels: Editions Ciaco, 1990).

6 Wolfram Kaiser, Christian Democracy and the Origins of European Union (Cambridge: Cambridge University Press, 2007), 181.

7 Anthony O'Mahony, 'The Vatican and Europe: Political Theology and Ecclesiology in Papal Statements from Pius XII to Benedict XVI', International Journal for the Study of the Christian Church, 9, 3 (2009), 177-194.

8 Blandine Chelini-Pont, 'Papal Thought', 131-146.

9 Ute Frevert et al., Emotional Lexicons. Continuity and Change in the Vocabulary of Feeling 1700-2000 (Oxford: Oxford University Press 2014). American Historical Review (AHR) Conversation, 'The Historical Study of Emotions', 117, 5 (2012), 1487-1531; Jan Plamper, The History of Emotions: An Introduction (Oxford: Oxford University Press, 2015); German History, 'Forum: History of Emotions', 28, 1 (2010), 67-80.

10 Joachim C. Häberlen and Russell A. Spinney, eds., 'Special Issue: Emotions in Protest Movements in Europe since 1917', Contemporary European History, 23, 4 (2014), 489-644.
} 
anticipation of the future (i.e. 'horizon of expectation'). ${ }^{11}$ Following this methodological framework, which is discussed in the first section, the second section outlines the formative experiences of Eugenio Pacelli, who would become Pope Pius XII in 1939. This serves two purposes. First, it sketches the tenor of Vatican diplomacy in the twentieth century. Second, it introduces us to the personal experiences that shaped his thinking about European unity as a pope. In the sections that follow three of Pius XII's major post-war encyclicals are examined: Communium Interpretes Dolorum, Fulgens Radiatur and Summi Maeroris.

Although Pope Pius XII made active use of the still relatively new medium of the radio and various other public statements to express his opinion on European integration, in this article we deliberately selected the encyclicals as object of study, because encyclicals have a special function within Catholic doctrine. They are authoritative papal documents which contain a moral message. Encyclicals explicitly include the assignment not only to receive this message, but also to share it and act where necessary. As indicated above, in that function they connect Catholic social doctrine to the European project. The three encyclicals analysed here were selected out of the total of forty-one encyclicals that Pius XII wrote, because of their relevance regarding the process of European integration. Most of the thirty encyclicals that Pope Pius XII wrote after the Second World War are theological at heart (e.g. Deiparae Virginis Mariae or Haurietis aquas in gaudio), focus on the atheist threat of communism (e.g. Luctuosissimi Eventus, Laetamur Admodum and Datis Nuperrime) or call for peace more generally (e.g. Mirabile Illud). Three encyclicals are explicitly concerned with European integration as such and, hence, selected for our analysis: Communium Interpretes Dolorum, Fulgens Radiatur and Summi Maeroris.

Our analysis unveils that these three encyclicals show a gradual development in style, from a more generic pastoral letter to more explicit political engagement. Communium Interpretes Dolorum, written in 1945, laments the damages of the war and calls for peace prayers. While the emotive of enmity is prevalent throughout this short encyclical, especially in reference to the current state of affairs, it focuses on a transition towards a just peace. This concept is empowered by an appeal to amity: more specifically, love. Fulgens Radiatur, through the metaphor of the hagiography of St. Benedict, reminds the reader of the Catholic foundations of righteous European leadership. In doing so, Fulgens Radiatur links the Catholic past to Pius XII's image of the present. It intends to remind the reader that only Catholic leadership can lead Europe to a progressive, brighter future. Past emotions of rivalry and contempt are linked to worldly leadership, while the Catholic alternative is validated by the master emotive of hope. Finally, Summi Maeroris has a more impassioned tone. It refers to the dangers to peace in the emerging Cold War, with a focus on the risks for the European continent. The focus in this encyclical is on the Other, rather than the Self, both in judgement and emotional appeal. What we notice in these encyclicals is that Pius XII gradually changed his diplomatic attitude into a more activist approach to European developments. Arguably, this characterises the development of his pontificate more generally, as well. ${ }^{12}$ Consistent throughout the encyclicals is the functionality of emotions to convey the message. The emotional vocabulary of Pius XII bridges the gap between theology and politics - aiming at a 'change of the heart'.

\section{Emotion Discourse Analysis}

Emotions are undeniably present in any political discourse, even if - and arguably, even more so if these are presented as depicting an 'objective truth'. Public statements, like the encyclicals of Pius XII,

11 Reinhart Koselleck, “'Space of Experience” and "Horizon of Expectation”: Two Historical Categories', Futures Past: On the Semantics of Historical Time (New York: Columbia University Press, 2005), 255-75.

12 While it is beyond the scope of this article to capture the full picture of the political engagement of the Catholic Church, others have pointed at this change from a withdrawn attitude to more political engagement. See, for example, Stathis Kalyvas, The Rise of Christian Democracy in Europe (New York: Cornell University Press, 1996), which refers to an development from an inward-looking Catholic Church that accepted little or no political commitment outside its own structures, to a gradual toleration of modern democracy in the first half of the twentieth century. 
are studded with emotionally charged discourses, emotives. In this context, emotions move beyond their natural realm of the personal experience and morph to an active form of persuasion: they change, build, hide or intensify emotions that are accepted and recognised in a readership. ${ }^{13}$ Whether explicitly working with this or unknowingly appealing to emotions, public authorities have a profound influence on their audience by their use of emotional vocabulary in public statements. Emotives can be a powerful tool to reconstruct images of past, present and future - either with reference to emotional vocabulary with a positive valence or with a negative valence. As both felt and expressed emotions are connected to our lived experience, time is an important aspect in our understanding of emotives. ${ }^{14}$

In our understanding of time, Reinhardt Koselleck's analytic distinction between experience and expectation proves helpful. According to Koselleck, our representations of time are oriented from the present, towards a past or future. ${ }^{15}$ The social environment grants a framework to individuals which affects their interpretation of the past. Specific past experiences inform the present, but our present perception of the past is limited to what Koselleck calls the 'space of experience': a (limited) integration of the many possibilities to interpret the past into a more or less coherent picture. ${ }^{16}$ All historical experience is unfolding at the same time and could never be grasped in full to determine our image of the present: the 'space of experience' is a scope. Consequently, the portrayal of certain experiences by authoritative persons has a potential impact in mobilising and manipulating of both the space of experience and the expectations of their readership. These expectations amount to a 'horizon of expectation', which anticipates a future as a product of individual and collective experiences. ${ }^{17}$ However, the horizon of expectation is not exclusively determined by experience. Experiences influence one another while unfolding and so does the horizon of expectation. Hopes, anticipations, calculations and assumptions alter the experience of any individual - and group. The horizon of expectation is 'that line behind which a new space of experience will open, but which cannot yet be seen' ${ }^{18}$ The future cannot be experienced itself, yet our 'horizon of expectation' does influence our experience of the present. Public figures can adjust that horizon by reflecting on certain possibilities for the future or emphasising the (un)importance of certain experiences for the future.

As such, the emotional vocabulary, the 'tool' to repaint any picture of present, past and future, is crucial in the persuasive function of public texts. It is by giving emotional value to certain experiences or expectations that they are framed in a certain way. This framework then influences the space of experience or horizon of expectation of the readership. This article studies that function of emotives with a focus on time, attitude and subject. Emotives associated with either past, present or future have a positive or negative valence (e.g. hope vs. fear) and may entail a certain judgement/qualification of the Self (e.g. shame, pride) or Other (e.g. contempt, empathy). ${ }^{19}$ The Self in this context is not the individual Pius XII, but is defined as his readership: specifically the patriarchs, primates, archbishops and all other ordinaries who follow the Roman Catholic Church, with the specific instruction to communicate the encyclical's desires and exhortations to the flocks entrusted to their care. ${ }^{20}$ In other words, the Self in this context constitutes all church officials, and by their extension, the Roman Catholic community in Europe. This threefold distinction between forward- and backward-looking emotives, directed at the Self or Other, in either a positive or negative way, provides the analytic framework for the emotion discourse analysis of the encyclicals of Pius XII. It allows us to detect the master

\footnotetext{
13 William M. Reddy, 'Emotional Expression as a Type of Speech Act', The Navigation of Feeling: A Framework for the History of Emotions (Cambridge: Cambridge University Press), 103-5.

14 Trineke Palm, 'Interwar Blueprints of Europe: Emotions, Experience and Expectation', Politics and Governance, 6, 4 (2018), 137.

15 Reinhart Koselleck, 'Space', 256.

16 Ibid., 259, 262.

17 Ibid., 260-3.

18 Ibid., 260-1.

19 Jonathan Haidt, 'The Moral Emotions', in R.J. Davidson, K.R. Scherer and H.H. Goldsmith, eds., Handbook of Affective Sciences (Oxford: Oxford University Press, 2003), 852-70.

20 This readership is specifically referred to at both the opening and closing of each encyclical.
} 
emotives of amity and enmity that tie off the 'space of experience' and 'horizon of expectation' and show how this encouraged a particular understanding of the urgency and direction of European integration.

\section{The Formative Experiences of Pius XII}

Pope Pius XII was born in Rome on 2 March 1876, as Eugenio Maria Giuseppe Giovanni Pacelli. The Pacelli family was part of the nobilità nera or papal nobility: nobles which had devoted themselves to the Vatican at the time of the struggles between the Papal States and the nascent Kingdom of Italy. Eugenio's grandfather Marcantonio served as deputy Minister of the Interior for Pius IX and stood at the foundation of l'Osservatore Romano. ${ }^{21}$ The young Eugenio enjoyed a relatively peaceful childhood and joined the Gregorian Pontifical University after his secondary education. In 1899 he was ordained a priest, and after his ordination he joined the papal secretariat of state. Soon, his career began to move towards the diplomatic path. In 1914, Eugenio Pacelli was recruited for the Sacred Congregation for Extraordinary Ecclesiastical Affairs, a relatively new congregation established to help the Holy See deal with secular states.

At the time when Pacelli developed his career in Vatican diplomacy, the Holy See was struggling to play an effective role in international affairs. Years of outright hostile relations between the papacy and the Italian unifying forces had resulted in the occupation of papal territories in 1870. This situation meant that the papacy had to find new ways to engage with a modern world, which requested new church-state relations. ${ }^{22}$ The Congregation for Extraordinary Ecclesiastical Affairs was emblematic for the new position of the Holy See, and Eugenio Pacelli was fully involved in this unfolding process. Later, Pacelli served in the diplomatic services for the Holy See's relations with Serbia, Austria-Hungary and Germany. Diplomatic instability and war were still pressing subjects when Pacelli was promoted to the rank of papal nuncio ${ }^{23}$ in 1917. Residing in the heart of Catholic Germany, Pacelli combined 'old' and 'new' diplomacy. On the one hand, the Vatican wished to renew the papal diplomatic position in Europe by working towards the status of an international broker of peace. As part of this, Pacelli was involved in the (unsuccessful) attempt to convince Emperor Wilhelm of a peace proposal to end the First World War. On the other hand, the Holy See continued to rely on a familiar toolbox: the traditional diplomacy of concordats. Pacelli himself was a vivid advocate of this old diplomatic tool. However, this combination of a new ambition with an old strategy was not entirely fruitful. Vatican claims to impartiality were met with scepticism, sometimes deliberately fostered by anti-clerical propaganda. ${ }^{24}$ Moreover, the concordat strategy had lost its traditional validity. New leaders such as Adolf Hitler changed the diplomatic field: the Reichskonkordat that the Holy See signed with Hitler in 1933 no longer meant safe stability, but an uneasy relationship with a leader who did not care for Vatican admonitions. ${ }^{25}$ Besides these

21 See, for the Pacelli family, George L. Williams, Papal Genealogy: The Families and Descendants of the Popes (Jefferson: McFarland \& Company, 2004). L'Osservatore Romano is the daily newspaper of the Vatican. It was first published on 1 July 1861, just a few months after the Kingdom of Italy was proclaimed. Marcantonio Pacelli served as deputy Minister of the Interior at that time and had expressed the wish to publish a more rhetorical journal next to the existing Giornale di Roma. Its first issues could be called rather polemical and were no doubt inspired by the tense situation in Rome. See for example http://www.vatican.va/news_services//or/history/hi_por.html.

22 The papal state (Stato della Chiesa) covered most of the modern regions of Lazio (which includes Rome), le Marche, Umbri and Emilia-Romagna until the capture of Rome in 1870 by Italian nationalists. Pius IX became known as a prisoner in his own house, a situation which entered the Vatican annals as the 'Roman Question'; see David I. Kertzer, Prisoner of the Vatican: The Popes, the Kings, and Garibaldi's Rebels in the Struggle to Rule Modern Italy (Boston/New York: Houghton Mifflin Company, 2004).

23 Papal representative, the rank of ambassador.

24 John Pollard, Benedict XV: The Unknown Pope and the Pursuit of Peace (New York: Continuum, 2005), 132-5.

25 Frank J. Coppa, ed., Controversial Concordats. The Vatican Relations with Napoleon, Mussolini and Hitler (Washington, DC: The Catholic University of America Press, 1999), 23. Rita Almeida de Carvalho provides a useful comparative overview which enlightens the delicate balance of these concordats in 'Interwar Dictatorships, the Catholic Church and 
diplomatic struggles, Pacelli's German years were also marked by formative experiences on a more personal level. In April 1919, a revolutionary group associated with communism managed to overthrow the local government in Munich. Even though the victory was short-lived, it had a deep emotional impact on Pacelli. During the unrest, communist revolutionaries broke into his residency and demanded his car. ${ }^{26}$ This 'communist threat' left a deep mark on Pacelli, fostering anti-communism that remained with him the rest of his life. ${ }^{27}$

In December 1929, Pacelli left his post in Germany to become Secretary of State for Pius XI. This high-ranking position practically made him one of the most important figures in the 'reinvented' Vatican City. ${ }^{28}$ Ten years later, the assembly of Cardinals elected Eugenio Pacelli as their new pope, on 2 March 1939. Pacelli took on the papal name Pius XII, in honour of his predecessor. For the newly elected Pius XII, European affairs turned out to be his major contest. This included pressing issues such as Mussolini's invasion of Albania in early April 1939 and the status of the Church in the increasingly Nazi Germany. The world waited with bated breath for a formal papal condemnation of the racial politics in Germany and of the illegitimate conquests of both the Italian and German powers. Pius XII, however, insisted on the same claim of Vatican impartiality which his predecessor had held during the First World War. Pius XII cherished Vatican impartiality at a cost which provoked British, French and American diplomats as well as the public. ${ }^{29}$ And even though observers deemed Pius XII's response grievously inadequate, incidents such as the Polish crisis of 1939 did not change his mind. ${ }^{30}$ This continued to be an issue throughout the war years. His diplomatic, rather than activist, course has been the source of criticism both during the Second World War and in more recent years. It has been stated that Pius XII, as the leader of the Catholic community, would have had a moral responsibility to condemn the aggression of the Axis. ${ }^{31}$ Others point to the risks involved if Pius XII would have antagonised fascist Italy and Nazi Germany by publicly denouncing their actions. ${ }^{32}$ Beyond the moral question of Pius XII's position and motivation for his more silent, diplomatic approach in the Second World War, the question of (limits to) papal influence is especially relevant in this context. Clearly, there was a desire for the morally authoritative voice of Pius XII, while at the same time he was not willing (or capable) to interfere in worldly European affairs. However, after the Second World War, Pope Pius XII gradually became more involved in the European project, outlining the contours of his Catholic blueprint of European integration.

\section{April 1945: Justice and Peace, Kissing Each Other}

On 15 April 1945, the end of the Third Reich seemed imminent for most Europeans. In the preceding month, Hitler had issued the Nero decree, Himmler had tried to negotiate peace with the Allies and

Concordats: The Portuguese New State in a Comparative Perspective', Contemporary European History, 25, 1 (2016), 37-55.

26 When their revolutionary leader, Kurt Eisner, was assassinated (by a Catholic) in 1919, unrest increased. Members of the communist Spartacus group entered Pacelli's residence to claim his valuables.

27 His anticommunism was a main inspiration for his post-war international efforts. See for example Chelini-Pont, 'Papal Thought', 136-7.

28 Less than a year before the return of Pacelli to Rome, the Lateran Treaties had been signed, leading to the establishment of Vatican City. The practical application of the treaties proved to be a matter of continuous dispute between the fascist and the papal state.

29 As becomes clear from several diplomatic letters of ambassadors. A letter from the nuncio in Paris opens with the telling editorial preface in the Acts and Documents of the Holy See: 'Certains secteurs de l'opinion française ont critiqué la démarche du Pape pour la paix. Le Nonce envoie plusieurs coupures, interprètes de cette tendance.' In 'Le nonce a Paris Valeri au cardinal Maglione, Paris, 21 June 1939', Actes et Documentes Santa Sede (ADSS), 1, 68, 182-3.

30 'Le ministre de Grande Bretagne Osborne a Mgr Tardini, Rome, 23 Aug. 1939', ADSS, 1, 111, 229-30.

31 The author John Cornwell goes as far to refer to Pius XII as 'Hitler's Pope'. During the lifetime of Pius XII, on several occasions (diplomatic) efforts were made to persuade Pius XII to make a statement against Nazi Germany - all to no or little effect. See also Robert Ventresca, Soldier of Christ, 146.

32 See for example Peter C. Kent, Lonely Cold War of Pope Pius XII: The Roman Catholic Church and the Division of Europe, 1943-1950 (Montreal: McGill-Queen's University Press, 2002). 
Churchill had symbolically crossed the Rhine. ${ }^{33}$ Europe was still suffering from a devastating war, but there were reasons to start thinking about a future after this war. For example, resistance movements developed blueprints for a post-war European order. Far from just being an economic and political endeavour, from its very start European integration was also a moral and spiritual affair, as it was conceived of by both the Catholic Church and ecumenical networks. ${ }^{34}$ Some founding fathers of the European community, such as Konrad Adenauer, Robert Schuman and Alcide de Gasperi, were devout Catholics. As such, they were receptive to the pope's stance on their initiatives.

In Spring 1945, the last public reflection of Pius XII on European affairs had been during his Christmas speech in December 1944. In this radio speech he had commemorated the sixth anniversary of the beginning of the war. He had hinted at the responsibilities of current and future leaders, to restore the European battlegrounds into a commonality of states:

In an ever growing array of noble spirits a thought arises, an ever clearer and more firm will: to make of this world war, of this universal upheaval, [a starting point for] a new era for deep renewal, total reordering of the world. [...] the men of government, responsible representatives of nations, gather in talks, in conferences, in order to determine fundamental rights and duties, on which a commonality of states should be reconstituted, to trace the path towards a better, safer, more worthy humanity. ${ }^{35}$

A few months later, Pope Pius XII elaborated on this line of thought. On 15 April 1945, he published the encyclical Communium Interpretes Dolorum, which translates as the Interpreter of Universal Anguish. In this short encyclical, Pius XII called on Europeans to terminate the devastating war. This relatively short message has abundant emotives of enmity, centred on a shared experience of war. The horizon of experience in Communium Interpretes Dolorum, however, is not limited entirely by this negative valence. Rather, it is focused on the master emotive of hope, empowered by amity and love for a just peace.

In the opening of Communium Interpretes Dolorum, Pius XII painted an impassioned picture of Europe: the continent being forced into discord, contention, stifled by distress and sorrow, blinded by hate and rivalry, destroyed by monstrous conflict caused by enmity. ${ }^{36}$ The encyclical dives deep into this set of emotions which all relate to grief caused by enmity. However, for Pius XII, that hostile space of experience did not necessarily dictate a dim horizon of expectation. In his effort to open this horizon of expectation and to envisage a more radiant future, he imagined an active European search for a just peace. In the argument of Pope Pius XII, 'Christian morals ${ }^{37}$ empower humanity in a way that allows for human reason and will. While the space of experience proved for Pius XII that humankind is not capable of exercising this free will and reason without boundaries, there was reason for him to hope. Pius XII's key for that transformation into a hopeful horizon of expectation was justice. His plea for justice was strengthened by emotives of amity:

33 Edward Davidson and Dale Manning, Chronology of World War Two (London: Cassell \& Co, 1999), 238-40.

34 On war-time blueprints for post-war European integration, see Walter Lipgens, ed., Documents on the History of European Integration, Vols 1 and 2 (Berlin: De Gruyter, 1985). See also: Jorrit Steehouder and Clemens van den Berg, 'A Wartime Narrative of Hope - The Freiburger Bonhoeffer-Kreis's 1943 Memorandum as a Blueprint for Europe', in Lennaert van Heumen and Mechthild Roos, eds., The Informal Construction of Europe (Abingdon: Routledge, 2019), 57-74. On the role of churches in European integration more broadly, see Sergei Mudrov, Christian Churches in European Integration (Abingdon: Routledge, 2016), 63.

$35 \mathrm{http} / / / w 2 . v a t i c a n . v a / c o n t e n t / p i u s-x i i / i t / s p e e c h e s / 1944 /$ documents/hf_p-xii_spe_19441224_natale.html, translation own.

36 Pius XII, Communium Interpretes Dolorum, Actae Apostolicae Sedis (AAS), vol. XXXVII no. 4, 97-100 (English translation used from Libreria Editrice Vaticana: page count starts at 1), 1,2. This image is reinforced by the strong passages such as: 'in the midst of such violent disturbances and tumults', lamentations about 'the peoples who have been forced into discord, contention', or references to 'their long-lasting distress and sorrow', and many more of these emotives.

37 Ibid., 1. 
If you do not love justice, you will not have peace, for these two love one another and kiss each other, so that if you practice justice, you will find peace kissing justice. [...] If therefore you desire to come to peace, do justice; avoid evil and do good. This is to love justice; and when you have already avoided evil and done good, seek peace and follow it. ${ }^{38}$

Justice in the mind of Pius XII was a specific, almost anthropomorphic concept which should be hold close, be experienced and loved even, for Europeans to find their desired peace. This specific call for a just peace could be explained if we recollect Pius XII's personal space of experience. In his position as papal nuncio, he had experienced first-hand the results of the punitive - and in that line of thought unjust - Treaty of Versailles: emotions of humiliation, frustration and anger had plunged Europe ino another world war. In Communium Interpretes Dolorum, Pius XII tapped into a similar set of emotions to charge his concepts of peace and justice. By doing so, he attempted to make political affairs a matter of the heart. Pius XII appealed to his readership to undergo an emotional change in order to arrive at a just peace.

[...] seek a true and sincere peace, that may quickly end this calamitous and bloody conflict. In the midst of such great destruction and perturbation of affairs, while many are still angry and inimical to one another, it is certainly not easy to achieve such a peace. Peace must be tempered by the impartial scale of justice, which embraces in fraternal charity all peoples and all nations and which does not bear hidden germs of discord and strife. ${ }^{39}$

The emphasis on equity and justice shows Pius XII's priority to promote stability and order and his aversion to elaborating on emotions relating to guilt and revenge. By describing the state of Europe in these strong emotives, he connected experiences to feelings that many of his readers may have recognised in their own recent past. With these emotives, Pius XII could intensify feelings of shock, and frame in a convincing way what he saw as the origins of this devastating war. That combination of negative emotions connected to the past, and the appeal of the positive 'just peace' in the future, empowers this encyclical. Pius aimed for a change in the hearts of his readership, breaking the vicious cycle of rivalry and vengeance.

\section{March 1947: A Shining Example}

In the years following the end of the Second World War, new challenges for Vatican diplomacy presented themselves. One of the major concerns for Pius XII was the rise of communism in the late 1940s: Eastern Europe was regrouping under the banner of the Soviet Union. Another factor on the world stage was the advance of the influence of the United States in Europe. The American interest included the Vatican: it has been estimated that American Catholic donations to the Roman Catholic Church translated into more than half of all Vatican revenues at the time. ${ }^{40}$ Pius XII knew that the Catholic world was expanding well beyond Europe and that it could be worthwhile to invest in this new, openly anti-communist superpower. Harry Truman, a deeply religious man, succeeded Franklin D. Roosevelt as President of the United States in 1946, and maintained strong ties with the Vatican. This cooperation was not limited to the Vatican only. Throughout Western Europe, Christian Democratic parties dominated the political scene. Their electoral success was largely indebted to the polarisation of the political landscape between communism and capitalism. Broad Church support for core European integration added legitimacy

\footnotetext{
38 Ibid., 1. This phrase was inspired not only by Psalms 84, but also by the writings of Augustinus of Hippo. Emphasis by the authors.

39 Ibid., 2.

40 Robert Ventresca, Soldier of Christ, 287.
} 
to transnational cooperation, with socialism as a common enemy. ${ }^{41}$ Although he insisted on papal neutrality, Pius XII was actively engaged in this societal development, through diplomatic ties and through public statements.

Pius XII published the encyclical Fulgens Radiatur ${ }^{42}$ a mere nine days after Truman announced his pledge to contain Soviet expansionism, known as the Truman Doctrine. This is not to say that Pius XII chose this moment because of the political events evolving at the time. On the contrary, the occasion on which Pius XII decided to publish this letter was medieval rather than contemporary: 21 March 1947 marked 1400 years after the subject of the encyclical, St. Benedict, 'happily exchanged this earthly exile for his heavenly country, ${ }^{43}$ Compared to the other two encyclicals, this encyclical stands out for its narrative character. It outlines the history of St. Benedict, set in the context of the decaying Roman Empire.

This particular reading of the story of St. Benedict is aimed at providing guidance in European affairs for the readership of Pope Pius XII. Pius XII mentions at the beginning of his encyclical that the 'shining example' of St. Benedict is intended to inspire his readership and to show that the Christian faith is a beacon in uncertain times. Therefore, while negative emotions prevail in the margin of this encyclical, the master emotive of Fulgens Radiatur has a positive valence. It is constituted of emotions relating to modesty, perseverance and hope. As harmony is pitted against turbulence in this encyclical, it is the notion of hope that effectively glues the arguments together, and which brings the centuries-old story of Saint Benedict into the twentieth century.

While the encyclical explains how in a time of barbarism, greed and a crumbling society, St. Benedict offered a hopeful alternative, the comparison with the function of the church in Pius XII's time is never far away. The demise of the Roman Empire and the opportunities offered by faith are described in passionate detail: 'Weakened and corrupt from within, it lay in mighty ruins in the West [...] In such a mighty storm and universal upheaval, from where did hope shine? Where did help and protection arise in order to save humanity and what was left of its treasures from shipwreck? It came from the Catholic Church'. ${ }^{44}$ Shortly after this statement, Pius XII connects this image to the present when adding:

If these norms, in virtue of which Benedict once illumined saved and built up the society of those turbulent times which was crumbling and even lead it back to better ways, be accepted and honoured universally today, then no doubt our age will be able to come safe from its terrifying shipwreck, make up its losses material and spiritual and adequately remedy its deep wounds. ${ }^{45}$

The role of time in this encyclical is important with regard to the function of emotional vocabulary. The space of experience, relating to the past, is peppered with emotions that appeal to feelings of anger and hate. However, this narrow and dark space of experience does not determine the horizon of expectation for Pius XII in this encyclical. This makes the space of experience, more than in the other encyclicals, multi-interpretable. In this encyclical, it has several functions. First of all, it is the emotional baggage that the reader can relate to. A society in ruins, feelings of despair, all these recognisable emotives for the contemporary come together in this medieval story. Second, it shows how the past needs to be addressed, how it is the necessary context of any future plans. And, relating to that, thirdly it shows what lessons need to be learned in order for the future to be different from the past. This shows how the past is related to but does not determine the future. On the contrary, it gives the readership agency: an opened-up horizon of expectation can be the result of an individual's

\footnotetext{
41 Wolfram Kaiser, Christian Democracy and the Origins of European Union (Cambridge: Cambridge University Press, 2007), 163-80.

42 A radiating shine (coming from Benedict of Nursia).

43 Pius XII, Fulgens Radiatur, Actae Apostolicae Sedis (AAS), vol. XXXIX, no.5, 137-155 (English translation used from Libreria Editrice Vaticana: page count starts at 1), 2.

44 Ibid., 2.

45 Ibid., 9.
} 
attitude towards the space of experience. In Communium Interpretes Dolorum, the space of experience was introduced as a given fact. In Fulgens Radiatur, the agency of St. Benedict offers an example to create a window of opportunity in an otherwise gloomy world. With the hagiography of Saint Benedict, Pius XII refers to a shared heritage that is valuable to his contemporaries. ${ }^{46}$

Fulgens Radiatur is a strong Catholic blueprint. The former encyclical, Communium Interpretes Dolorum, primarily contains an outcry to his readership to ensure the right conditions for European peace. In Fulgens Radiatur, Pius XII is more concerned with setting an example of the Catholic lifestyle, explicitly linked to the welfare of society. For this argument, Pius XII primarily appeals to the emotional array of his audience.

The assignment in this encyclical is therefore primarily directed at the Self, the followers of the Catholic Church in Europe. They should strive not for worldly vices but for eternal blessings. That, and not worldly power, is the 'shining example'. ${ }^{47}$ At the same time there is also a message for those who can be considered the Other. At some points in the encyclical, Pius XII specifically addresses them, warning that 'Pontiffs, give greater security to the city by religion than by the encircling walls ${ }^{48}$ and 'religion alone provides the support for what is right and honourable'. ${ }^{49}$ The readership of Pius XII is implicitly warned to avoid confusing state authority with the universal Christian call to mankind. The particular place in history that Pius XII assigns to St. Benedict is telling in this respect. Catholicism is generally regarded as relatively favourable toward supranational institutions. ${ }^{50}$ Catholicism in itself has a (moral) authority that exceeds the national level. Therefore, the nation-state is not the ultimate organisation level. In Fulgens Radiatur, this tendency is recognisable, as St. Benedict functions as an example for the larger unity of Europe rather than the local or national level. However, at the same time, Fulgens Radiatur shows how this European vision is conditionally related to Christian morals and leadership. A peaceful coexistence guided by amity was, in the image of Pius XII, only provided for by God and a Christian lifestyle: in other words, by following the lead of the Catholic Church.

\section{June 1950: Of the Deepest Sorrow}

Three years after the publication of Fulgens Radiatur, in 1950, the Cold War had not diminished. On the contrary, Germany had split into two in 1949 and the Korean War broke out in June 1950. By now the Holy See had become increasingly opposed to communism. Severe persecution and mass deportation of Catholics in Eastern Europe led Pius XII to issue a decree against communism in 1949, in which he declared that any Catholic who professed the communist doctrine would be excommunicated as apostate. ${ }^{51}$ Pius XII's personal strong aversion to communism, developed during his time in Germany, only increased and was embedded in a wider Catholic debate in Italy over communist influence. ${ }^{52}$ Not only was communism an outspoken atheist ideology, it offered a utopian narrative which directly interfered and competed with Christian narratives of charity and fraternity. Pius XII's repudiation of communism was unequivocal, and even though the Vatican persisted in its claims to papal neutrality, the Vatican interests coincided most closely with those of the Western powers.

46 St. Benedict was later declared patron saint by Pope Paul VI, in 1964. See Michael David Knowles, 'St. Benedict', Encyclopeedia Britannica online, https://www.britannica.com/biography/Saint-Benedict-of-Nursia.

47 Pius XII, Fulgens Radiatur, 8.

48 Ibid., para. 25.

49 Ibid., para. 26.

50 Brent Nelsen, James Guth and Cleveland Fraser, 'Does Religion Matter? Christianity and Public Support for the European Union', European Union Politics 2, 2 (2001), 267-91.

51 M. Mazgaj, Church and State in Communist Poland: A History, 1944-1989 (Jefferson: McFarland \& Company, 2010), 5455. For the decree, see: Supreme Sacred Congregation of the Holy Office (approved by Pius XII), AAS, XXXXI (1949), $340-5$.

52 Renato Moro, 'The Catholic Church, Italian Catholics and Peace Movements: The Cold War Years, 1947-1962', Contemporary European History, 17, 3 (2008), 365-90. 
From the start, Pius XII saw the advance of communism as a European dilemma. ${ }^{53}$ Against this backdrop, Summi Maeroris reads like a more activist encyclical than the former two. In contrast to Fulgens Radiatur's message of hope, for example, in Summi Maeroris the backward-looking master emotive of grief is central to understand the emotional quality of this encyclical. Effectively, the title of the encyclical was translated as Of the Deepest Sorrow. Fulgens Radiatur was focused on setting an example for the Catholic - appealing to the emotions of the Self, the readership. The Sorrow of Summi Maeroris, however, is preoccupied with the Other rather than the Self:

[in] not a few countries, falsehood instead of truth has been presented under a certain guise of reasonableness; not love, nor charity have been fostered, but hatred and a blind rivalry are being encouraged; not concord among citizens is exalted, but disturbance and disorder are being provoked. $^{54}$

While still not mentioning his opponents by name, by these references, Pius XII unmistakably engaged with communist forces in Europe. Almost directly addressed at the statesmen of the time, Summi Maeroris was a blueprint of Europe as much as it was a warning.

Let all of them remember what war brings in its wake, as we know only too well from experience nothing but ruin, death and every sort of misery. ${ }^{55}$

Against the inimical space of experience, the desired horizon of expectation in Pius XII's mind was that of Christian virtue. Like the former two encyclicals, the key for Pius XII was the return to a Christian lifestyle, a return to a 'natural' Christian order. For Pius XII, European identity and purpose had to be embedded in Christian communal functions and obligations. In that sense, his Catholic blueprint differs considerably from any appeal to territory, ideology or nationalism. Pius XII's horizon of expectation is built on moral, not geographical or ethnic grounds. The value of emotives in Summi Maeroris shows the particularity in which the encyclicals interact with European developments. As a middle way between strict theology and open politics, Pius XII connected the religious beliefs of Catholicism with the process of European integration. And in this connection, Pius XII became more outspoken. Rather than ending this encyclical with a call for prayer for the miserable (as in Communium Interpretes Dolorum) or a financial contribution to restore the Abbey of Montecasino (in Fulgens Radiatur), Pius XII asked his readership to 'teach all this with frankness'. ${ }^{56}$ It clearly aims to mobilise his audience to respond, from a Catholic perspective, to European affairs.

\section{Connecting Images of European Past, Present and Future: Papal Blueprints of Hope}

Churches, the Catholic Church in particular, had a unique role in the early phase of the post-war European integration process. Pope Pius XII, as leader of the Catholic Church from 1938 to 1958, helped to set the scene. The current emotion discourse analysis of the post-war European encyclicals of Pius XII's Communium Interpretes Dolorum, Fulgens Radiatur and Summi Maeroris shows how Pope Pius XII integrated emotional and religious vocabulary to (re)construct an image of a European past and future.

In terms of content and tone, the three texts differ considerably. In the first encyclical, Communium Interpretes Dolorum, Pius XII called on all Christians, especially children, to pray for wisdom, while encouraging the political leaders of Europe to alter their behaviour. The second encyclical, Fulgens

\footnotetext{
53 Frank J. Coppa, The Life and Pontificate of Pope Pius XII: Between History and Controversy (Washington, DC: The Catholic University of America Press, 2013), 204.

54 Pius XII, Summi Maeroris, AAS, vol. XXXXII no.10, 513-517. English translation used from Libreria Editrice Vaticana: page count starts at 1), 1, para. 2 .

55 Ibid., 2.

56 Ibid., 3 .
} 
Radiatur, reads as a hagiography of Saint Benedict. It refers to a shared experience of an earlier process of European integration and disintegration (i.e. the rise and demise of the Roman Empire) as a metaphor of the contemporary state of European affairs. Lastly, Summi Maeroris clearly reflects the increased tensions with communism. At the time of writing, Catholics were persecuted in the eastern part of Europe and this urgent situation is reflected in the level of political engagement of Summi Maeroris.

Despite their superficial differences, what appears to be a consistent force in the encyclicals is the function of emotions to convey the message. Our historical approach to emotion discourse analysis helps to understand this. It surpasses the focus on any strategic motives of Pius XII, just as it does not solely focus on theology. By studying the texts through the prism of emotion discourse analysis, we can see the functionality of the text in a broader context.

Post-war Europe was a time in which Europeans tried to re-invent the economic, political and moral pillars of their continent. At the time, there were considerable political and non-political alliances which were trying to shape Europe as a Christian-Democratic community, based on shared values and economic interest. In this context, Pius XII wrote his encyclicals, which were neither politically nor economically bounding, yet had great moral authority. If we then turn to the function of emotional vocabulary in these texts, we see how the texts of Pius in fact support the image of the Catholic community - a community with emotional war-time baggage, but with a moral mission towards the future. What these three encyclicals share is their appeal to the emotional mindset. Pius XII was explicitly looking for a change beyond diplomacy or reason: a change of hearts. Pius XII made in all three an urgent appeal to his readership to strive for peace on a Catholic foundation. Considerations of the past, the present and the (desired or feared) future formed the pillars upon which Pius XII built his argument.

We see this function of emotional vocabulary on several levels. The concept of just peace in Communium Interpretes Dolorum is empowered by an appeal to emotions: in order to arrive at justice, one must be able to love. In other words: the tool for Pius XII to make his claim for just peace valid is to appeal to the emotions of his readership. Fulgens Radiatur also makes use of emotions to transfer the moral, almost political, message. Pius XII explicitly sets the life of St. Benedict in a turbulent, frightening, rivalrous time. By making references to his present, he leaves little doubt that the emotions appealed to in this hagiography are a metaphor for a bitter contemporary state of European affairs as well. Moreover, while these negative emotions function to create recognition among readers, it is the positive emotions linked to hope that give the text its strength and relevance. Literally a 'shining example', the Christian lifestyle and its obedience to the Catholic Church of St. Benedict is what should give rise to a hopeful horizon of expectation. The Catholic Church as an alternative to the secular powers is thus substantiated by appealing to emotions. Finally, in Summi Maeroris, negative emotives are predominant. Pius XII's rejection of communism is conveyed to his readers by explicitly referring here to emotional concepts such as enmity and sorrow.

The functionality of emotional vocabulary is crucial in the encyclicals for various reasons. Emotives bridge the gap between theology and politics. Especially in an era when the Catholic Church no longer exercised direct secular power, we see how the Holy See is unquestionably still involved in the reconstruction of a war-torn continent. Furthermore, we can consider the function of the emotional vocabulary in the light of Pius XII's own personal experiences. Emotion discourse analysis reveals how personal experiences are reflected in public works, such as the encyclicals of Pius XII. In addition, studying emotional vocabulary is an appealing method for a type of source that is specifically aimed at a 'change of the heart'.

In sum, we argue that emotion discourse analysis provides for a systematic way to historicise the relationship between (religious) ideas and emotions and study the evolving process of post-war European integration. The oeuvre of Pius XII still offers countless possibilities to better examine the function of emotives beyond the European integration project. A comparative perspective, including of predecessors or successors, would help illuminate the continuity and change in the emotional valence of religious concepts. Moreover, a comparative analysis with ecumenical voices on European 
integration during the same era would further contribute to our understanding of the particular relationship between religious vocabulary and emotions.

Acknowledgements. The authors would like to thank Dr. Kim Knibbe and the Blueprints team for their constructive feedback: Prof. Dr. Beatrice de Graaf, Prof. Dr. Peter-Ben Smit, Prof. Dr. Mathieu Segers, Clemens van den Berg and Jorrit Steehouder.

Cite this article: Lanting D, Palm T (2022). 'Change the Heart, and the Work Will Be Changed': Pius XII's Papal Blueprints for Europe. Contemporary European History 31, 100-112. https://doi.org/10.1017/S0960777321000151 